\title{
Value of the Estimation of Thyroglobulin Levels in the Surveillance of Treated Differentiated Thyroid Carcinoma
}

\author{
By Ch. Sulman, P. Gosselin, Ph. Carpentier and B. Lemaire \\ Department of Nuclear Medicine (Doctor Ch. Sulman), \\ Center Oscar Lambret (Director: Professor A. Demaille), Lille, France
}

(Received May 2/October 31, 1983)

Summary: Thyroglobulin levels were measured, without interruption of hormone treatment, in 115 patients who had undergone thyroidectomy for differentiated carcinoma.

Thyroglobulin levels were invariably high in patients with iodine fixing metastases. The estimation of thyroglobulin was found to be more sensitive than the detection of metastases by their uptake of 131 iodine. A new protocol is suggested for monitoring treated differentiated carcinoma.

Der Wert der Bestimmung der Thyroglobulinkonzentration für die Uberwachung des behandelten differenzierten Schilddrüsencarcinoms

Zusammenfassung: Bei 115 Patienten, wegen eines differenzierten Carcinoms thyroidektomiert, wurde die Thyroglobulinkonzentration bestimmt, ohne daß die Hormonsubstitution unterbrochen wurde.

Die Thyroglobulinkonzentrationen waren bei Patienten mit Iod-fixierenden Metastasen unverändert hoch. Die Bestimmung von Thyroglobulin erwies sich als empfindlicher als der Nachweis von Metastasen auf Grund ihrer ${ }^{131} \mathrm{I}$-Aufnahme. Ein neues Vorgehen für die Ưberwachung behandelter differenzierter Carcinome wird vorgeschlagen.

\section{Introduction}

After total thyroidectomy and destruction of any residual cervical thyroid tissue by 131-iodine, the monitoring of treated thyroid carcinoma was based essentially upon the detection of ectopic areas with uptake of 131-iodine. This investigation required the interruption of substitution hormone therapy for a sufficiently long period ( 3 weeks) to enable the metastasis to take up the iodine. This method is not without problems. The repeated administration of 131-iodine results in significant irradiation. In particular, the hypothyroidism resulting from the interruption of treatment is a source of considerable difficulties in the family and professional life of the patients, and the increase in thyrotropin (thyroid stimulating hormone, TSH) levels related to the interruption of treatment could favour the increase in proliferation of recurrences or of the metastases.
Can the estimation of thyroglobulin levels without the interruption of substitution hormone therapy replace the isotope studies using 131-iodine? The present study was aimed at providing an answer to this question.

\section{Materials and Methods}

\section{Estimation of thyroglobulin}

This estimation was made using a radioimmunological technique with the Tg RIA "Henning" kit distributed in France by Hoechst Behring. An accuracy profile (fig. 1) was undertaken using the method of Ekins on 10 standard curves. The maximum relative error was $19.2 \%$ for the point $6.25 \mu \mathrm{g} /$, and lies between 2.6 and $4.8 \%$ for the other points of the curve; this results in an absolute error between $1.2 \mu \mathrm{g} / 1$ for the lowest standard $(6.25 \mu \mathrm{g} / \mathrm{l})$ and 14 $\mu \mathrm{g} / \mathrm{l}$ for the highest standard point $(400 \mu \mathrm{g} / \mathrm{I})$. In the zone where the error should be minimal, i.e. between $6.25 \mu \mathrm{g} / \mathrm{l}$ and $100 \mu \mathrm{g} /$. it is quite acceptable since it lies between 1.2 and $1.3 \mu \mathrm{g} /$. Study 
of intra-assay reproducibility showed a variation coefficient between 1 and $2.3 \%$. Inter assay reproducibility, determined for 27 sera from patients measured twice in two different batches, proved to be satisfactory. The $t$ test applied to the mean of the differences between these 2 paired series does not show significant differences $(t=0.27)$. Tests of parallelism confirmed a good correlation between the theoretical values and the observed results. The correlation coefficient is 0.97 with a regression line $y=$ $0.91 x+0.88$. The recovery test was satisfactory with recovery rates between 81 and $92 \%$.

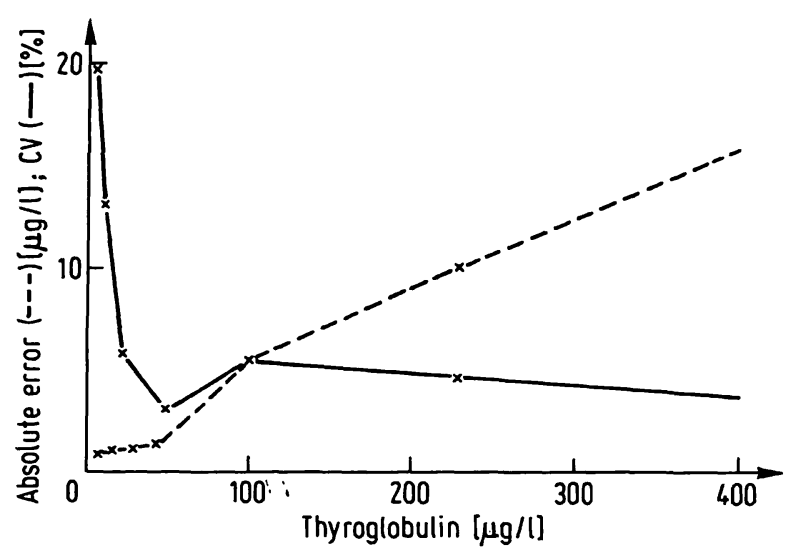

Fig. 1. Precision profile of thyroglobulin estimation.

\section{Patients}

The study was undertaken with 115 patients all of them with total thyroidectomy and attending the nuclear medicine department for a spell of 2 months.

Only patients with anti-thyroglobulin antibodies were rejected. These antibodies were detected with a commercial kit of the "Commissariat à l'Energie Atomique" (CEA). Six patients were seen for the first complementary treatment with 131-iodine. All the other patients had already received 131-iodine. The survey period lies between 1 month and 13 years. There were 86 females and 29 males with a mean age of 48.3 years and extremes of 13 and 81 years. These 115 patients were divided into 23 with papillary carcinomas, 33 with well differentiated follicular carcinomas and 59 with moderately differentiated follicular carcinomas. All measurements of thyroglobulin were made during continuing hormone therapy. This consisted of triiodothyronine for 101 patients, thyroxine for one and triiodothyronine plus thyroxine for the 13 remaining patients. The posology was adapted so that the thyrotropin level was low and did not rise after an injection of $250 \mu \mathrm{g}$ of thyroliberin (thyrotropin releasing hormone, TRH).

\section{Whole body 131-iodine scanning}

For all the patients the whole body 131 -iodine scanning was performed with $37 \mathrm{MBq}(1 \mathrm{mCi})$ of 131 -iodine and after a sufficiently long period of withdrawal of thyroid hormone so that the thyrotropin levels were greater than $80 \mathrm{mU} / \mathrm{l}$. The search for ectopic fixation of 131-iodine was made with whole body scanning 4 days after ingestion of $37 \mathrm{MBq}(1 \mathrm{mCi})$ of 131 -iodine. The measurement was made with a collimated probe so that a whole transverse slice could be studied with the same sensitivity. The sensitivity of the system is almost $185 \mathrm{kBq}(5 \mu \mathrm{Ci})$ of 131 -iodine i.e. $0.5 \%$ of the ingested dose. When a deviation is detected a scintigraphy is performed in that region with a $400 \mathrm{~T}$ General Electric Gamma-
Camera.

\section{Results}

Among the 115 patients (tab. 1), 89 had a thyroglobulin level lower, and 26 a level higher than 6.25 $\mu \mathrm{g} / \mathrm{l}$.

Tab. 1. Results of thyroglobulin assay. ' '

\begin{tabular}{|c|c|c|c|}
\hline . & & $\begin{array}{l}\text { Thyro- } \\
\text { globulin } \\
<6.25 \mu \mathrm{g} / 1\end{array}$ & $\begin{array}{l}\text { Thyro- } \\
\text { globulin } \\
>6.25 \mu \mathrm{g} / 1\end{array}$ \\
\hline & $\mathbf{n}$ & $\mathbf{n}$ & $\mathbf{n}$ \\
\hline $\begin{array}{l}\text { No residues, } \\
\text { no metastasis }\end{array}$ & 85 & 81 & 4 \\
\hline Residue alone & 7 & 4 & 3 \\
\hline $\begin{array}{l}\text { Non fixing metastasis } \\
\text { alone }\end{array}$ & 14 & 4 & 10 \\
\hline Fixing metastasis alone & 6 & 0 & 6 \\
\hline $\begin{array}{l}\text { Residues }+ \\
\text { non fixing metastasịs }\end{array}$ & 1 & 0 & 1 \\
\hline $\begin{array}{l}\text { Residues }+ \\
\text { fixing metastasis }\end{array}$ & 2 & 0 & 2 \\
\hline Total & 115 & 89 & 26 \\
\hline
\end{tabular}

The 89 patients with low thyroglobulin levels were divided into 81 with neither residues nor metastases, 4 with residues only and 4 with non=fixing metastases only. In this group none of the patients with low thyroglobulin levels had any ectopic uptake of 131-iodine. Among the 4 patients with non fixing metastases, 3 were studied before and after withdrawal of hormonal treatment. The thyroglobulin levels were always lower than $6.25 \mu \mathrm{g} / 1$.

Among the 26 patients with thyroglobulin levels higher than $6.25 \mu \mathrm{g} / \mathrm{l}, 4$ had neither residues nor metastases in spite of a complete check up with clinical and laryngologic examinations, whole body 131-iodine scanning, whole body bone scintigraphy with methylene diphosphonate of $99 \mathrm{~m}$-technetium, chest radiography and thoraco-abdominal computed tomography. The thyroglobulin levels were relatively low (two with $9 \mu \mathrm{g} / \mathrm{l}$ and two with $13 \mu \mathrm{g} / \mathrm{l}$ ) probably corresponding to occult metastases. 10 patients had non fixing metastases. In 5 of these patients, the metastases were detected before the thyroglobulin assay or at the time of it. The thyroglobulin levels were $17,80,105,150,160 \mu \mathrm{g} / \mathrm{l}$. In 3 patients, the metastases were in the lungs, in one patient in the bones, and in the bones and the mediastinum of the other patient. In the 5 other patients the thyroglobulin levels were $70,75,80,125,155 \mu \mathrm{g} / \mathrm{l}$. The metastases were detected from 3 months to 18 months after the first increase in the thyroglobulin lèvel. The metasta- 
ses occurred twice in the lungs, twice in the bones and once in the mediastinum. In the 6 patients with fixing metastases, thyroglobulin levels were between $68 \mu \mathrm{g} / 1$ and $250 \mu \mathrm{g} / \mathrm{l}$. In two of these patients, with levels respectively of $130 \mu \mathrm{g} / \mathrm{l}$ and $155 \mu \mathrm{g} /$, treatment with 131-iodine resulted in isotopic sterilisation and at the same time there was normalisation of thyroglobulin levels. Six patients had residues. In 3 patients, the residues were isolated. In the other 3, there was an association of fixing ( 2 cases) and nonfixing (1 case) metastases.

Among the 23 patients with metastases, only 8 had uptake of 131-iodine showing a low sensitivity: $35 \%$. On the other hand as the existence of ectopic fixation of 131-iodine may be considered to be pathognomonic, the specificity of the whole body 131 iodine scanning is $100 \%$.

For the thyroglobulin assay, our results show a sensitivity of $83 \%$ and a specificity of $95 \%$ (tab. 2).

Tab. 2. Sensitivity and specificity of whole body 131 -iodine scanning and thyroglobulin radioimmunoassay.

Whole body scinti- Thyroglobulin graphic detection radioimmunoassay with 131-iodine

\begin{tabular}{lrr}
\hline Sensitivity & $35 \%$ & $83 \%$ \\
Specificity & $100 \%$ & $95 \%$ \\
\hline
\end{tabular}

\section{Discussion}

The existence of functional thyroid residues after total thyroidectomy could not be determined by the estimation of the thyroglobulin level, since 4 of the patients out of the 7 studied with residues had thyroglobulin levels below $6.25 \mu \mathrm{g} /$. However a very high thyroglobulin level in patients with residues could be indicative of a suspicion of metastasis.

According to some authors $(1,2)$, the detection of metastasis both by isotopic methods as well as by the estimation of thyroglobulin level can only be carried out validly after complete destruction of cervical residues.

Many authors have established the interest of thyroglobulin assay for the surveillance of thyroid carcinomas $(1-11)$. Some of them think that the assay must be combined with the whole body 131-iodine scanning (12-15). For others the assay after withdrawal of the hormonal treatment can replace the whole body 131 -iodine scanning $(1,8-10,16-20)$. Those authors feel that we cannot estimate the thyroglobu- lin level during hormonal treatment because of the proved increase in thyroglobulin level as well as thyrotropin level $(12,13,17,21)$. They consider that the sensitivity of the method decreases when the hormonal treatment is not stopped.

On the other hand for some authors the real interest of thyroglobulin is that it can be studied without the withdrawal of hormonal treatment. Although it is well known that the thyroglobulin level increases as well as the thyrotropin levels, it seems that withdrawal of hormonal treatment does not increase the sensitivity of thyroglobulin measurement $(2,4-7$, 22). Black et al. (4) even found that the thyroglobulin assay best reflects the state of the patients when the hormonal treatment is continued.

These differences from one author to another are perhaps due to the different normal levels used by these authors. One author (3) even proposed different normal ranges, depending whether the patient is under hormonal treatment or not. If one can consider that the existence of thyroglobulin in the serum is pathologic (more than $6,25 \mu \mathrm{g} / \mathrm{l}$ for our method) for patients without any residual tissue, then we feel that the assay can be carried out under hormonal treatment. This is borne out by our results.

All patients with anti-thyroglobulin antibodies were eliminated before the study. This limitation in the method would involve some $10 \%$ of cases of differentiated thyroid carcinoma.

On the basis of these features, it would seem that a method can be proposed for the monitoring of treated differentiated carcinoma of the thyroid. Total destruction of thyroid tissues by 131 -iodine is made after thyroidectomy. The absence of uptake of 131-iodine is confirmed after three months. In the absence of residues, thyroglobulin estimation replaces the detection of iodine fixing metastases. The latter is performed only if the thyroglobulin level is above $6.25 \mu \mathrm{g} / 1$. In this way, it is possible to avoid the detection of iodine fixing metastases after the interruption of hormone therapy in approximately $80 \%$ of cases (in fact thyroglobulin levels were below 6.25 $\mu \mathrm{g} / \mathrm{l}$ in 85 patients out of 105 in our study).

\section{Conclusion}

The estimation of thyroglobulin level as a method for the detection of metastasis of treated differentiated thyroid carcinomas is more sensitive than whole body 131-iodine scanning. The latter technique presents some disadvantages and should be performed only when the thyroglobulin level is high, which reduces its indications by $80 \%$. 


\section{References}

1. Barsano, C. P., Shosey, C., de Groot, L. J. \& Refetoff, S. (1982) Arch. Intern. Med. 142, 763-767.

2. Schlumberger, M., Fragu, P., Travagli, J. P., Gardet, P., Lumbroso, J., Charbord, P., Lacour, J. \& Parmentier, C. (1982) Nouv. Presse Med. 11, 3101-3105.

3. Ashcraft, M. W. \& van Herle, A. J. (1981) Amer. J. Med. 71, 806-814.

4. Black, E. G., Cassoni, A., Gimlett, T. M. D., Harmer, C. L., Maisey, M. N., Oates, G. D. \& Hoffenberg, R. (1981) Lancet II. 443-445.

5. Bottger, I., Dirr, W. \& Pabst, W. (1980) NucCompact 11 , 147-153.

6. Bottger, I., Kanitz, W. \& Pabst, H. W. (1982) HTG RIA: Problems and clinical value in follow-up of differentiated thyroid carcinoma. In: Proceedings of the 3rd World Congress of Nuclear Medicine and Biology (Raynaud, C., ed.) Pergamon Press, Paris, Vol. 4, pp. 2799-2802.

7. McGoudall, I. R. \& Bayer, M. F. (1980) Clinical Seimeo 21, 741-744.

8. Pacini, F., Pinchera, A., Giani, C., Grasso, L. \& Baschieri, L. (1980) Clin. Endocrinol. (Oxf.) 13, 107-110.

9. Schneider, A. B., Line, B. R., Goldman, J. M. \& Robbins, J. (1981) J. Clin. Endocrinol 53, 1199-1206.

10. Tang Fui, S., Hoffenberg, R., Maisey, M. \& Blac, E. (1979) Br. Med. J. 2,; 298-300.

11. Van Herle, A. J., Uller, R. P., Matthews, N. L. \& Brown, J. (1973) J. Clin. Invest. 52, 1320.

12. Castagnoli, A., Forni, S., Milani, S., Pupi, A. \& Cappelli, G. (1982) Pitfalls of serum thyroglobulin assay in the follow-up of differentiated cancer of the thyroid. In: Proceedings of the 3rd World Congress of Nuclear Medicine and Biology (Raynaud, C., ed.) Pergamon Press, Paris, Vol. 4, pp. 2791-2794.
13. Colacchio, T. H. A., Lo Gerfo, P., Colacchio, D. A. \& Feind, C. (1982) Surgery $91,42-45$.

14. Echenique, R. L., Kasi, L., Haynie, T. H. P., Glenn, H. J., Samaan, N. A. \& Stratton Hill, C. (1982) J. Nucl. Med. 23, $235-240$.

15. Roti, E., Robuschi, G., Emanuele, R.; Bandini, P., Russo, A., Riva, P., Galassi, E., Guerra, U. P., Manfredi, A., Bozzetti, A., Guazzi, A. M. \& Gnudi, A. (1982) Endocrinol. Invest. 5, 43-46.

16. Hufner, M., Grussendorf, M. \& Pollman, H. (1980) The value of thyreoglobulin $(\mathrm{Tg})$ measurements in the follow-up of patients with differentiated carcinoma of the thyroid. 6th Internat. Congr. of Endocrinology. Melbourne/Australia, February 10-16th (abstr. 292).

17. Hufner, M. \& Kimmig, B. (1981) Acta Endocrinol. (Kbh) Suppl 240, 13-14.

18. Hufner, M., Pollmann, H., Grussendorf, M. \& Schenk, P. (1980) Schweiz. Med. Wochenschr. 110, 159-162.

19. Hufner, M., Stumpf, H. P., Grussendorf, M., Hermann, H. J. \& Kimmig, B. (1982) Acta Endocrinol. (Kbh) Suppl. 246, 59-60.

20. Jansch, A., Heinze, H. G. \& Hast, B. (1981) Strahlentherapie $157,381-392$.

21. van Herle, A. J. \& Uller, R. P. (1975) J. Clin. Invest. 56, 272.

22. Speich, P. V., Coururier, M., Mollet, E. \& Bidet, R. (1982) J. Biophys. Med. Nucl. 6, 3-7.

Dr. Ch. Sulman

Service de Médecine Nucláire

Centre Oscar Lambret

Rue Frédéric Combemale

F-59020 Lille Cedex 